\title{
LITHOSTRATIGRAPHIC CORRELATION AND RESERVOIR CHARACTERISATION OF TRIASSIC SEDIMENTS IN KNEJA-ISKAR AREA (CENTRAL NORTH BULGARIA)
}

DOI: http://dx.doi.org/10.18509/GBP.2015.05

UDC: 551.761:553.98.04(497.2)

\author{
Assoc. Prof. Dr. Nikola Botoucharov \\ Diana Angelova, BSc. \\ Sofia University “St. Kliment Ohridski”, Bulgaria
}

\begin{abstract}
The research object is Triassic reservoir strata reached by boreholes in Kneja-Iskar area, Pleven region. The study area is located in the western part of Central North Bulgaria and falls within the scope of the Moesian Platform. The interest of many years is due to oil and gas shows, the majority of which are in the Triassic sedimentary complex.

The main objectives of the paper are the compilation of Triassic lithostratigraphic correlation scheme in the study area, separation and characterization of reservoir intervals by drilling and logging data.

Well log methods are used most often in the oil and gas exploration practice and undoubtedly are one of the most effective in the correlation of sedimentary sections and characterization of the reservoirs. The correlation between well sections in Kneja-Iskar area demonstrates the following Triassic lithostratigraphic units from top to bottom Kozlodui, Komshtitsa, Preslav, Russinovdel, Mitrovtsi, Doirentsi and Alexandrovo Formations. We investigated oil-, gas- and water-saturated horizons, reservoir layers and units and clarify their spatial distribution, bedding conditions and rock properties in the study area.

Reservoirs are represented by permeable carbonate rocks of Doirentsi, Mitrovtsi and Russinovdel Formations - limestones, dolomites and to a lesser extent, dolomitic limestones. Reservoir levels are primarily located in MiddleTriassic regional permeable complex. They are characterized by relatively low capacity and open porosity is generally in the range of $1.5-5.0 \%$. The Carnian zonal permeable unit is defined by significantly lower qualities and open porosity values are around 1.1-1.3\%. The reservoirs are three types with prevalent fractured type (limestones in wells R-1 Kneja, R-3 Kneja and R-1 Pelovo and dolomitic limestones in R-1 Pelovo) and secondary fractured-porous type (dolomite and limestone in the R-1 Pelovo) and fractured-porous-cavernous type (dolomites in R-1 Pelovo).

There are several oil and gas shows, bitumen and water dissolved gases in tested well sections. The hydrocarbons are with similar physical properties and chemical composition as oil and gas from economic fields in Central North Bulgaria.
\end{abstract}

Keywords: Moesian Platform, lithostratigraphic correlation, Triassic reservoirs, permeable carbonates, open porosity 


\section{INTRODUCTION}

The research object of the paper is the Triassic Formations and reservoirs reached by boreholes/wells in Kneja-Iskar area, Pleven region (Fig. 1). Their quality is determined by the lithological composition as well as depositional and post depositional burial conditions. Besides the detailed observation of the Triassic Formations the spatial distribution of the different permeable zones is also clarified.

The study area is located in the western part of Central North Bulgaria within the Moesian Platform (Fig. 2). The long-standing interest is due to oil and gas accumulations in the Triassic sedimentary complex. The hydrocarbon fields and numerous shows are accumulated in heterogeneous reservoirs the majority of which are in Middle Triassic carbonate rocks of Doirentsi Formation.

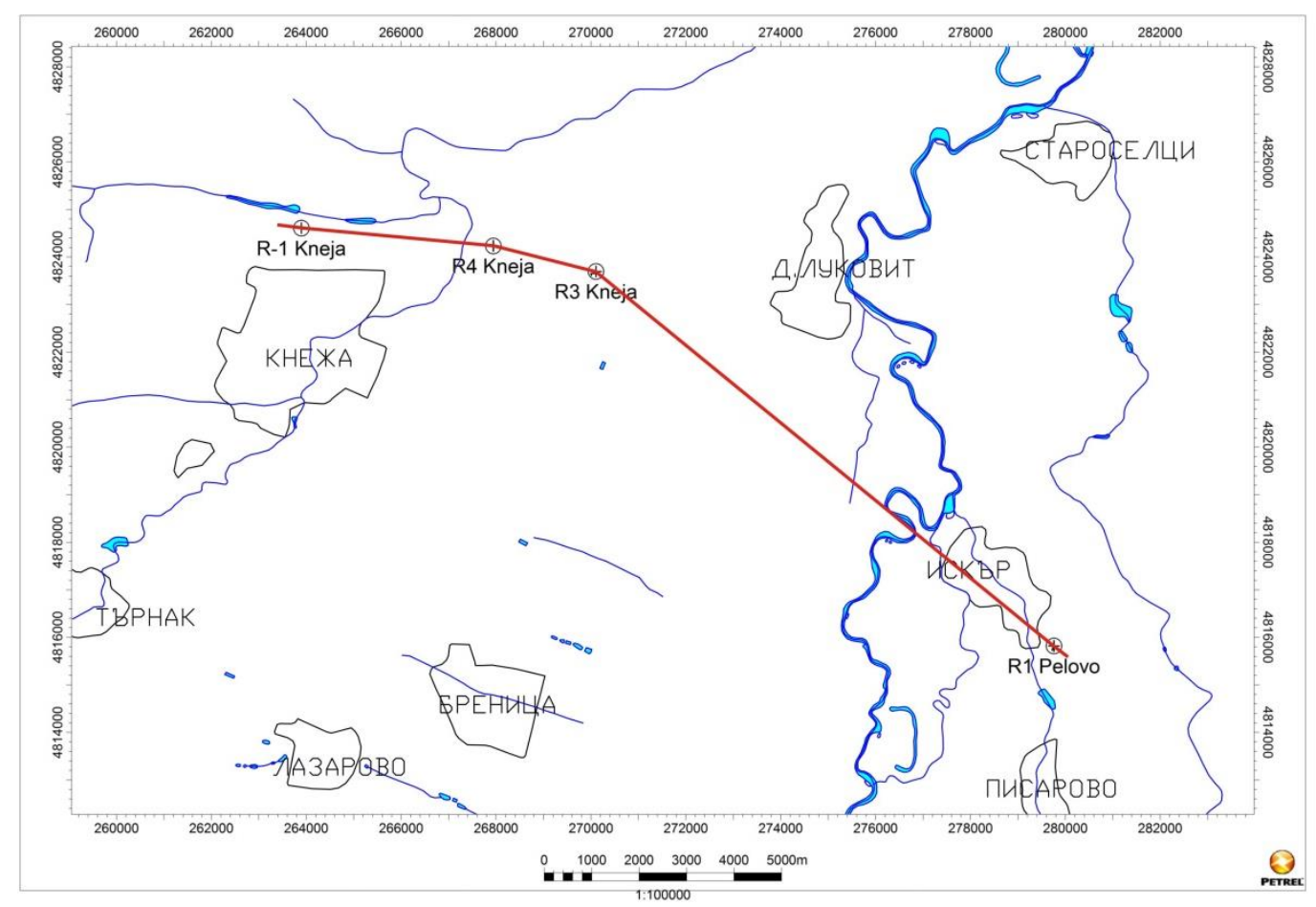

Fig. 1. Location map of the study area and correlated wells in Central North Bulgaria.

The main objectives of the paper are the compilation of Triassic lithostratigraphic correlation scheme, localisation and characterization of reservoir intervals by drilling and logging data in the study area.

\section{GEOLOGY}

The Northern Bulgaria is occupied by Moesian Platform (Fig. 2). The sedimentary platform succession, locally thick up to $12-13 \mathrm{~km}$ in western part, is composed by Paleozoic, Mesozoic and Neozoic sequences, covering a pre-Paleozoic methamorphic basement. The Triassic sequence comprises continental and dominantly shallow marine sediments with thickness more than $1200 \mathrm{~m}$ in study area. Their total thickness is strongly influenced by the depth of erosion. 


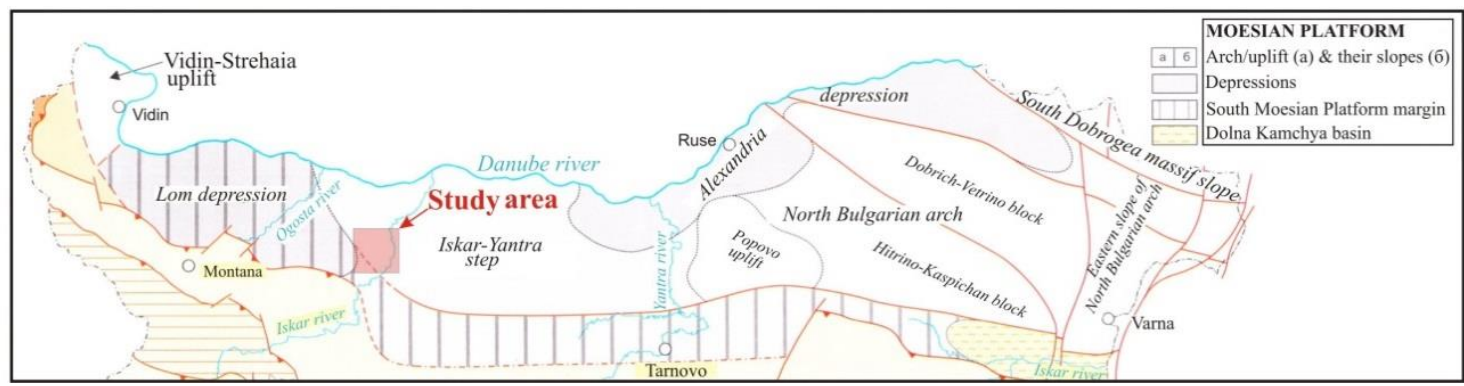

Fig. 2. Tectonic map of the North Bulgaria with study area (after [2]).

The study area fall in the western part of Iskar-Yantra step and in southeastern part of the neighboring Lom depression, both in the Moesian Platform. The oldest drilled rocks are Lower Triassic clastics that are reached by wells R-3 Kneja and R-1 Pelovo. The other investigated wells R-1 and R-4 Kneja end up in Middle Triassic carbonates and Upper Triassic mostly terrigenous deposits. The burial depths of the Triassic series vary from about $3080 \mathrm{~m}$ up to more than $4500 \mathrm{~m}$ and increases southward towards the South Moesian Platform margin (Fig. 2).

Lom depression is the most deeply buried part of the Moesian platform [1,2]. The unit is filled with almost continuous sequence of shallow to deep marine Mesozoic and Neozoic sediments with thickness exceeding 5-6 km.

The Iskar-Yantra step of Moesian Platform was formed as a single morphostructural unit in Jurassic-Lower Cretaceous carbonate complex [3]. There is differentiated block structure in Triassic structural plan. Regionally, the subsidence of the sedimentary complexes is from east to west and from north to south. The southwestern part of IskarYantra step is occupied by Pleven block.

The Pleven height is a distinct positive structure located at a higher hypsometric level compared to Ribenski graben from north and Tuchenitsa step from south [4]. The block is characterized by a relatively complete Triassic section and with well-defined morphotectonic forms. In the direction from east to west it is experiencing regional subsidence. The Triassic section is filled in and increases its thickness in the same direction.

\section{LOG DATA AND METHODS}

Well log methods and cuttings and well core observations are used most often in the oil and gas exploration practice and undoubtedly are one of the most effective in the correlation of sedimentary sections and characterization of the reservoirs. We compared the well cross-sections in Kneja-Iskar area, using the composition of the Triassic rocks (lithology), texture and their structural features and petro-physical characteristics to the official lithostratigraphic scheme (Fig. 3). Geophysical survey methods, including logs, are very important because they allow investigation of the rocks and outlining the lithological boundaries. We analyzed the methods of electric resistivity (Res) and the spontaneous potential (SP) and additionally for R-3 and R-4 Kneja there are gamma ray/neutron gamma ray logging (Fig. 4). The main criterion for the correlation is configuration of curves. We mark and trace the characteristic positive and negative anomalies encountered in all log diagrams. When comparing the Triassic sedimentary section in wells and the separation of lithostratigraphic units we establish not only the similarities and common features, but also differences. 
We investigated also oil-, gas- and water-saturated horizons, reservoir layers and units and clarify their spatial distribution, bedding conditions and rock properties in the study area by various well and drill steam tests.

\section{TRIASSIC LITHOSTRATIGRAPHIC CORRELATION AND RESERVOIR CHARACTERISATION}

The correlation between well sections in Kneja-Iskar area demonstrates the following Triassic lithostratigraphic units from top to bottom - Komshtitsa, Kozlodui, Preslav, Russinovdel, Mitrovtsi, Doirentsi and Alexandrovo Formations (Fig. 3 and 4).

Alexandrovo and/or Milinkamak Formation is drilled only in two of the wells R-3 Kneja (from 4500 to $4516 \mathrm{~m}$, thickness $16 \mathrm{~m}$ ) and R-1 Pelovo (from 4292 to $4300 \mathrm{~m}$, the thickness of $8 \mathrm{~m}$ ). In these boreholes the Formation is intersected only in the upper part, while in R-1 and P-4 Kneja never reached, because they are shallower (Fig. 4). The Formation consists of varied sediments, which realize the transition from red terrigenous toward grey carbonate rocks dated as Lower Triassic series with single fossil finds. There is an alternation of rusty-brown breccia-conglomerates, sandstones, calcareous shales, siltstones, red-brown, clayey, grey-green and grey-white limestones, dolomites, pyroclastic and volcanic sedimentary rocks. The presence of pyroclastic is not typical for Alexandrovo Formation in Central North Bulgaria. Looking in details of the spatial distribution of Triassic lithostratigraphic units in Moesian Platform towards the Forebalkan it can be presumed complex lateral relationships and contacts with Milinkamak Formation, especially in the southwestern part of the study area. Manifestations of volcanic activity have been established in several places in the Moesian platform (Kneja, Pelovo and Galata-Shumen) as well as mainly in the edge of the West Forebalkan (Chiren, Veslets, Goliamo Peshtene, Drashan and Varbitsa).

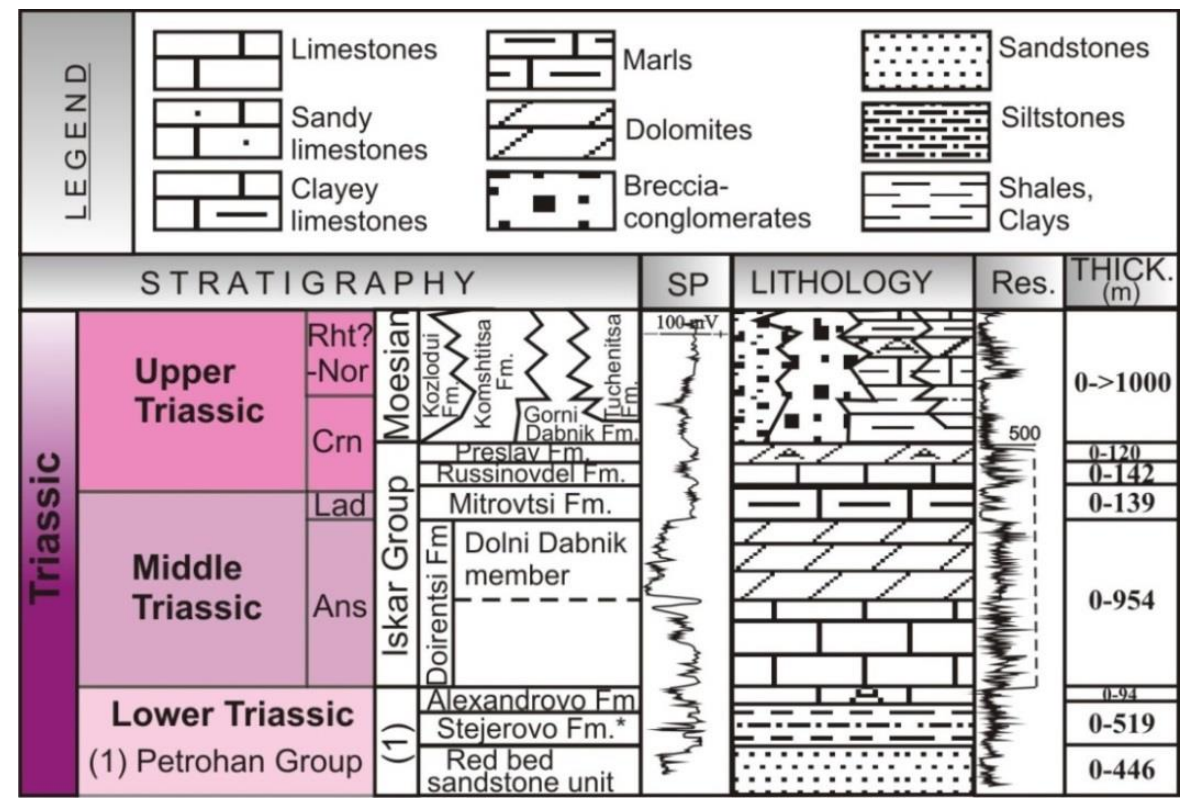

Fig. 3. Triassic lithostratigraphy and representative log features in Central North Bulgaria. *Stejerovo Formation is missing to the west of Iskar river in the study area.

Doirentsi Formation is described in the wells R-1 Kneja of 4124 to 4276 m (thickness $152 \mathrm{~m}$ ) and R-3 Kneja of 4090 to $4500 \mathrm{~m}$ (thickness $410 \mathrm{~m}$ ). In R-1 Pelovo the Formation is from 4020 to $4292 \mathrm{~m}$ (thickness $272 \mathrm{~m}$ ), where in the upper part Dolni Dabnik member 
is developed only here in the study area from 4020 to $4092 \mathrm{~m}$ with thickness of $72 \mathrm{~m}$ (Fig. 4). Doirentsi Formation is composed mainly of dolomites, limestones and marls. Dolomites are gray to cream color with hidden crystallinity, thick, strong and firm. The limestones are gray to dark gray with a cream shade, strong, thick and hard. The gray marls are relatively hard with uneven fracture and intercalated with limestones. The strata are dated Anisian stage by ostracods and single foraminifers.

Mitrovtsi Formation is passed throughout in three wells - R-1 Kneja of 3906 to $4124 \mathrm{~m}$ (thickness $218 \mathrm{~m}$ ), R-3 Kneja of 3895 to $4090 \mathrm{~m}$ (thickness $195 \mathrm{~m}$ ) and R-1 Pelovo in depth of 3875 to 4020 meters with thickness of 145 m (Fig. 4). The Formation consists mainly of siltstones, sandstones, limestones and marls. Shales are dark gray to black, brittle. Sandstones are of whitish to light gray color. There are quartz-mica clay minerals with dolomitic cement. Sandstones are fine-grained, slightly porous. The limestones are whitish, grey, grey-cream to brown. They are dense, hard and slightly fractured with shale and siltstone seams. The transition between the limestones, marls and shales is gradual with no abrupt boundary between them. Mitrovtsi Formation is defined as Middle-Upper Triassic series (Ladinian stage-Lower Carnian substage) proven by wide range of biostratigraphic data.

Russinovdel Formation is disclosed in three of the four wells at depths 3764 to 3906 meters in R-1 Kneja (thickness 142 m), R-3 Kneja from 3770 to 3895 m (thickness 125 $\mathrm{m}$ ) and R-1 Pelovo from 3796 to $3875 \mathrm{~m}$ (thickness $79 \mathrm{~m}$ ), (Fig. 4). The Formation consists of limestones and dolomites. The limestones are grey-cream color, creamywhite, dark grey with shade of dolomitization, grey-green, light brown and soft in some places. Otherwise dense, strong and solid. Dolomites are isometric, often with rhombohedral shape of the crystals. Their color is white, creamy dark and there are dark gray to black piebald markings in places. Also dense, hard with uneven fracture. Upper Triassic series (Carnian) dated with rare fossil finds.

Preslav Formation is drilled in wells R-1 Kneja from 3644 to $3764 \mathrm{~m}$ (thickness $120 \mathrm{~m}$ ), R-3 Kneja from 3656 to $3770 \mathrm{~m}$ (114 m) and R-1 Pelovo from 3697 to $3796 \mathrm{~m}$ with thickness of $99 \mathrm{~m}$ (Fig. 4). There is mainly alternation of dolomites and anhydrite. They are light gray to gray with cream shade, dense, hard with uneven fracture. In the base of the Formation we also discovered marls and shales of Pisarovo member with a thickness of 5 to $25 \mathrm{~m}$. Upper Triassic series according to the position in the section, due to a lack of biostratigraphy data.

Komshtitsa and Kozlodui Formations are characterized by a complex relationship in the study area (Fig. 3). In the western part of the North Komshtitsa Formation covers the sediments of Kozlodui Formation or wedges among sediments. They are both present in all four investigated boreholes (Fig. 4). In well R-1 Kneja the complex is with a thickness of $237 \mathrm{~m}$ between 3407 and $3644 \mathrm{~m}$; in R-4 Kneja is only 12 meters from 3288 to 3300 $\mathrm{m}$; and in R-3 Kneja is with thickness of $438 \mathrm{~m}$, between 3218 and $3656 \mathrm{~m}$; and in well R 1 Pelovo is with thickness $622 \mathrm{~m}$, from 3075 to $3697 \mathrm{~m}$. There is an alternation of siltstones, sandstones and shales, spotted colored with mostly rusty brown, violet and gray-green color. There is also cream-colored to grey-black limestones. Formation sediments are brittle, fragile and with uneven fracture. Breccias and brecciaconglomerates composed of limestone fragments with angular and irregular shape and to a lesser extent also present in rounded cuts. 


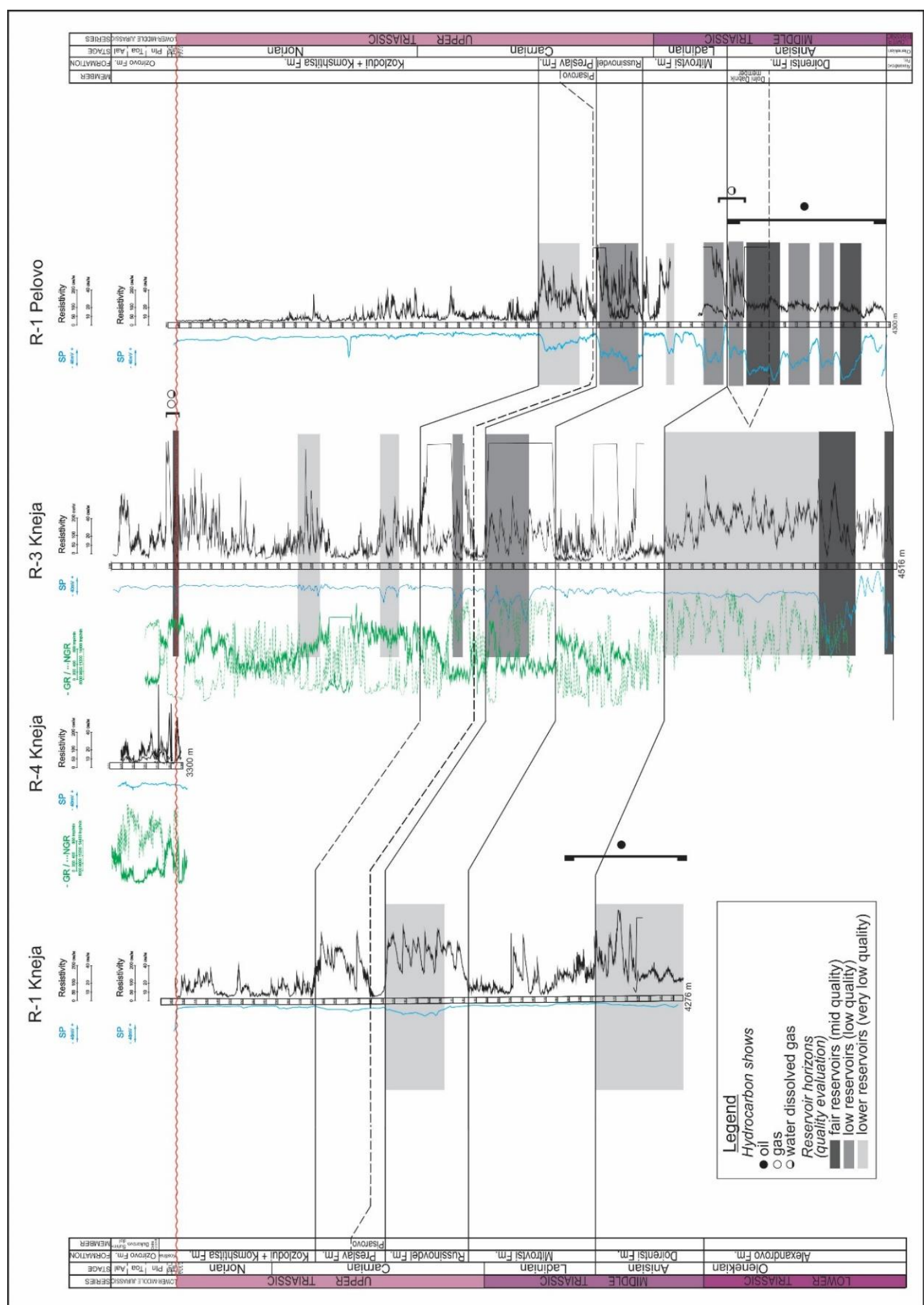

Fig. 4. Lithostratigraphic correlation of Triassic series with reservoir horizon delineation and hydrocarbon shows in profile line R-1 Kneja - R-4 Kneja - R-3 Kneja - R-1 Pelovo.

There is marl debris with marl-sandy cement. The chronostratigraphic position is Carnian-Norian-probably Rhaetian stage, based on indirect evidence because the sections are poor in biostratigraphic data. 
The well $\log$ methods are extremely useful when delineating the exact boundaries between lithological and/or lithostratigraphic units, clarifying the different types of rocks and identifying or comparing individual bodies in well cross sections. The importance increases in our case, because of the limited volume of core material in wells.

Most easily traced boundaries are these from Iskar carbonate group with prevalence of limestones and dolomites (Fig. 4). In Doirentsi, Russinovdel and Preslav Formations the well log curves (Resistivity and SP) for carbonate bodies are clearly distinguishable by their high electrical resistivity and relatively higher permeability compared to other sediments. There is distinctive record of the electrical resistivity and spontaneous potentials of Dolni Dabnik member dolomites, which are present only in well R-1 Pelovo. The well log curves for Mitrovtsi Formation are uneven and curly, especially in well R-1 Pelovo, because of the litofacies diversity. The presence of limestone is marked with a distinctive negative anomaly of SP and higher electrical resistivity characteristic of permeable carbonates.

Well log diagrams of Kozlodui + Komshtitsa Formations are relatively "smooth and calm" without prominent anomalies (Fig. 4). Clastics often named "exo-clastics" of limestone breccia-conglomerates and marls are more distinguishable with increase of electrical resistivity in well R-3 Kneja, where the thickness and presence of carbonate debris is greatest $(438 \mathrm{~m})$, and to a lesser extent in the P-1 Pelovo (thickness $237 \mathrm{~m}$ ).

The reservoirs evaluation of Triassic sediments in the borehole sections was performed using the complex interpretation of well log diagrams and in particular of the spontaneous potential (SP); lithological characteristics of the drilled rocks with attention to clayey, more dense and impermeable and/or permeable intervals clearly distinguishable on gamma ray $\log$ (GR) and neutron-gamma ray log (NGR); and the results of the well and drill steam tests.

We set three categories of reservoir horizons in descending order, depending on the measured porosity and permeability and registered well log curve anomalies, which are clearly distinguishable in Fig. 4:

1. Fair reservoirs, which are characterized by SP peaks toward the negative anomaly. They are marked with the dark grey color and have mid quality with open porosity between 3 and $10 \%$ and permeability up to $10-50 \mathrm{mD}$;

2. Low reservoirs, which are characterized by not so distinctive SP negative anomalies. They are marked with a light grey color and have a low (modest) quality with open porosity between 1 and $3 \%$ and permeability up to 5-10 $\mathrm{mD}$;

3 . Lower reservoirs, which do not differ with negative anomalies or those anomalies are insignificant. They are marked with the bright grey color and have very low quality with open porosity up to $1 \%$ and permeability up to $5 \mathrm{mD}$.

The Triassic reservoirs show variety and heterogeneity, distinguishing them from other Mesozoic deposits. Reservoirs are represented by permeable carbonate rocks of Doirentsi, Mitrovtsi and Russinovdel Formations - limestones, dolomites and to a lesser extent, dolomitic limestones. Reservoir levels are primarily located in MiddleTriassic regional permeable complex. They are characterized by relatively low capacity and open porosity is generally in the range of $1.5-5.0 \%$. The Carnian zonal permeable unit is defined by significantly lower qualities and open porosity values are around $1.1-1.3 \%$. The reservoirs are three types with prevalent fractured type (limestones in wells R-1 Kneja, R-3 Kneja and R-1 Pelovo and dolomitic limestones in R-1 Pelovo); secondary fractured-porous type (dolomite and limestone in the R-1 Pelovo); and fractured-porous-cavernous type (dolomites in R-1 Pelovo). 
There are oil shows in well R-1 Kneja from Doyrenska and Mitrovska bent in interval 4073-4276 m (Fig. 4). They are the same type of those tested in the Middle Triassic sediments in R-1 Pelovo and with non-economic character. The tests of the bottom of Ladinian represented by Mitrovtsi Formation (interval 3977-3997 m) demonstrate gas shows and water dissolved gases without any clear formation water influx.

\section{CONCLUSION}

The detailed correlation between investigated well sections in Kneja-Iskar area delineates the following Triassic lithostratigraphic units from top to bottom - Komshtitsa, Kozlodui, Preslav, Russinovdel, Mitrovtsi, Doirentsi and Alexandrovo Formations.

Reservoir horizons are primarily located in Middle Triassic regional permeable complex. They are characterized by relatively low quality and open porosity is generally up to $5.0 \%$.

The reservoirs are three types - fractured type in limestones in all investigated wells and dolomitic limestones in R-1 Pelovo; secondary fractured-porous type in dolomites and limestones and fractured-porous-cavernous type in dolomites east of Iskar River.

There are several oil and gas shows and water dissolved gases in Doirentsi and Mitrovtsi Formations. All hydrocarbons are with similar physical properties and chemical composition.

Acknowledgements: The authors thank the National Resources and Concessions in Ministry of Energy, Bulgaria for providing the geological, geophysical and well data.

\section{REFERENCES}

[1] Dabovski, C., Boyanov, I., Khrischev, Kh., et al. Structure and Alpine evolution of Bulgaria, Geol. Balc., vol. 32, nos. 2-4, pp 9-15, 2002.

[2] Zagorchev, I., Dabovski, C. \& Nikolov, T. (Eds.). Geology of Bulgaria. Volume II. Mesozoic geology. S., Acad. Publishing house „Prof. Marin Drinov”, 766 p, 2009. (in Bulgarian).

[3] Atanasov, A., Bokov, P., Georgiev, G. \& Monahov, I. Major features in geological structure of North Bulgaria in relation to the oil and gas perspectives. NIPI writings, vol. 1, pp 29-41, 1984. (in Bulgarian).

[4] Bokov, P., Monahov, I., Popov, S. \& Atanasov, A. Tectonic zoning. In: Atanasov, A. \& Bokov, P. (Eds). Geology and oil and gas perspectives of the Moesian Platform in Central North Bulgaria. S., Technics, pp 78-81, 1983. (in Bulgarian). 